\title{
CLIMATE-RADIAL GROWTH RELATIONSHIPS OF NORTHERN LATITUDINAL RANGE MARGIN LONGLEAF PINE (PINUS PALUSTRIS P. MILL.) IN THE ATLANTIC COASTAL PLAIN OF SOUTHEASTERN VIRGINIA
}

\author{
ARVIND A. R. BHUTA ${ }^{1 *}$, LISA M. KENNEDY ${ }^{1}$, and NEIL PEDERSON ${ }^{2}$ \\ ${ }^{1}$ Department of Geography, 115 Major Williams Hall, Virginia Tech, Blacksburg, VA 24061, USA \\ ${ }^{2}$ Department of Biological Sciences, 235 Moore, Eastern Kentucky University, 521 Lancaster Ave., Richmond, KY 40475, \\ USA
}

\begin{abstract}
Climate and longleaf pine (Pinus palustris P. Mill.) radial growth relationships have been documented within its southern and western distribution. However, knowledge of this relationship is lacking along its northern latitudinal range margin (NLRM). Based on the principles of ecological amplitude, limiting factors, and studies of coniferous species in eastern temperate forests of the U.S., we hypothesized that the radial growth of longleaf pine in mixed pine-hardwood forests is responding to winter temperatures in southeastern Virginia. Two longleaf pine chronologies were developed to determine the relationship between radial growth and monthly temperature, precipitation, and Palmer Drought Severity Index (PDSI) via response function analysis (RFA). Results at the 0.05 level yielded significant response function coefficients with a positive response to current winter temperature and precipitation and a negative response to prior August PDSI. In studies of climate and longleaf pine radial growth in other parts of its range, winter temperature and precipitation have not shared a significant positive association with radial growth. Instead current spring and summer precipitation usually share this positive association. These findings add more evidence to an emerging pattern suggesting that winter temperatures contribute to limiting the radial growth of temperate conifers at northern range margins in the Northern Hemisphere.
\end{abstract}

Keywords: Dendroclimatology, Pinus palustris, restoration, northern latitudinal range margin, response function analysis.

\section{INTRODUCTION}

The relationship between climate and radial growth throughout a tree species' geographical range and distribution is important to forest management and restoration so that land managers can be informed of predictions of a tree species response to future climate change (Cook and Cole 1991; Cook et al. 1998; Iverson et al. 1999; Tardif et al. 2001; Mäkinen et al. 2002; Pederson et al. 2004; Hopton and Pederson 2005; Zhang and Hebda 2004; Hoshino et al. 2008). Based on the principles of ecological amplitude, limiting factors, and the concept that tree species' range limits are

*Corresponding author: bhutaaa@vt.edu; Telephone: +13345593265 likely constrained by climate, radial growth of species at their northern latitudinal range margins (NLRMs) should be constrained predominantly by temperature (Shreve 1914; Fritts 1976). This relationship does not hold true for some broadleaved species. For example, white oak (Tardif et al. 2006), chestnut oak (Quercus montana Willd.), northern red oak (Q. rubra L.), and pignut hickory (Carya glabra P. Mill.) (Pederson et al. 2004) lack a winter temperature response at their NLRMs. However, cool winter temperatures have been documented as limiting radial growth for a few temperate coniferous and broad-leaved species in eastern North America along their NLRMs, specifically loblolly pine (Pinus taeda L.) in Arkansas and eastern Maryland (Cook et al. 1998), American beech (Fagus grandifolia Ehrh.) 


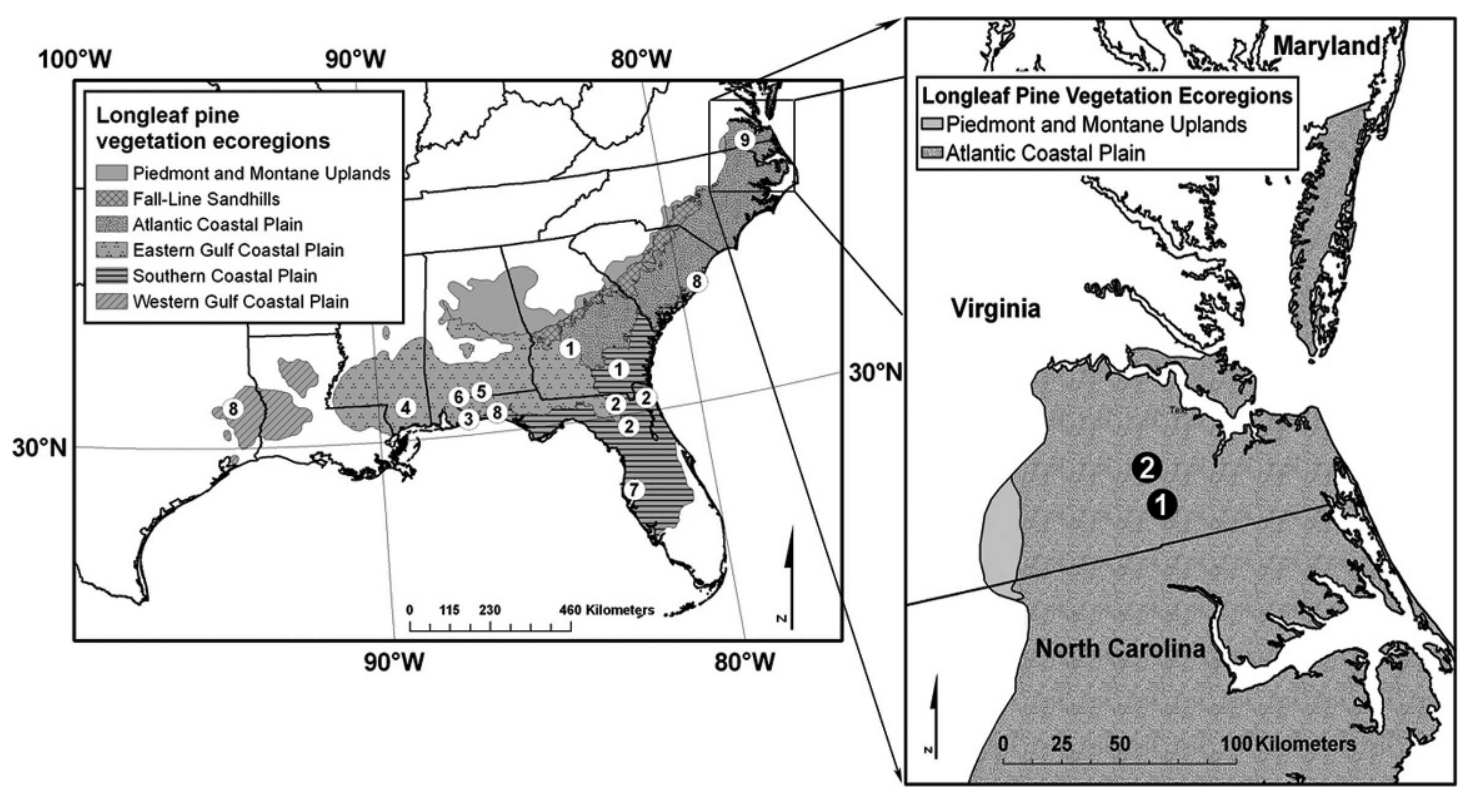

Figure 1. Longleaf pine ecoregions (modified from Peet 2006). Numbered circles represent dendroclimatological research on longleaf pine: 1 = Coile (1936); 2 = Shumacher and Day (1939); 3 = Lodewick (1940); 4 = Devall et al. (1991); 5 = Zahner (1989); 6 = Meldahl et al. (1999); 7 = Foster and Brooks (2001); and 8 = Henderson and Grissino-Mayer (2009); and $9=$ this study.

and eastern hemlock (Tsuga canadensis (L.) Carr.) in southern Quebec, Canada (Tardif et al. 2001), Atlantic white cedar (Chamaecyparis thyoides (L.) B.S.P.) throughout southern New England and eastern New York State (Pederson et al. 2004; Hopton and Pederson 2005), and pitch pine (Pinus rigida P. Mill.) in the Hudson River Valley of the United States (Pederson et al. 2004). These findings suggest that these and possibly other species might have a positive growth response to warming if it is not accompanied by substantial moisture deficits.

Regarding the climate response of the southern yellow pines in the southeastern temperate forests of North America, loblolly pine's climate response is the best-studied. A study of loblolly pine across its range indicates its radial growth is limited by cool January and February temperatures at its NLRM in eastern Maryland and February temperatures and as it approaches its NLRM in Arkansas (Cook et al. 1998). Other southern yellow pines have been studied in other portions of their range including loblolly pine (Friend and Hafley 1989; Grissino-Mayer et al. 1989; Travis and Meentemeyer 1991), shortleaf pine (Friend and Hafley 1989; Travis and Meen- temeyer 1991; Grissino-Mayer and Butler 1993), slash pine (Foster and Brooks 2001; Ford and Brooks 2003), and longleaf pine (Lodewick 1930; Coile 1936; Schumacher and Day 1939; Meldahl et al. 1999; Devall et al. 1991; Zahner 1989; Foster and Brooks 2001; Henderson and Grissino-Mayer 2009). The effects of climate on growth of the other southern yellow pines, longleaf pine (Pinus palustris $\mathrm{P}$. Mill.), shortleaf pine (Pinus echinata $\mathrm{P}$. Mill.), and slash pine (Pinus elliottii Englem.) at their NLRM however, remain essentially understudied. Climate-growth relationships for these species are important because they are both ecologically significant and important economic resources for the southeastern United States, which could be impacted by global climate change (Iverson et al. 1999).

Dendroclimatological research on longleaf pine has been ongoing for almost eighty years focusing mainly on intact forests of the Southern Coastal Plain and Eastern Gulf Coastal Plain longleaf pine vegetation ecoregions (Peet 2006; Figure 1). Lodewick (1930); Coile (1936); Schumacher and Day (1939); Meldahl et al. (1999); Foster and Brooks (2001), and Henderson and Grissino-Mayer (2009) identified significant cor- 
relations of radial growth with precipitation and drought between March and October of the current year in the Eastern Gulf and Southern Coastal Plains ranging from the northwestern panhandle of Florida through southern Alabama to southeastern Georgia and northeastern Florida. In the Eastern Gulf Coastal Plain, Zahner (1989) showed that summer weather, particularly drought, influenced radial growth in southern Alabama whereas in southern Mississippi, current year August precipitation, September temperatures, and February Palmer Drought Severity Index (PDSI) were positively associated with radial growth (Devall et al. 1991). Like some of the other southern yellow pines, knowledge regarding the climate-growth relationship for longleaf pine is lacking along its northern range limit.

The objectives of this study were to (1) develop longleaf pine chronologies from longleaf pine in Virginia, (2) determine which climatological variables influence longleaf pine growth, and (3) contribute to a better understanding of the spatial variability of longleaf pine radial growthclimate relationships throughout its range. Our results aim to provide a better understanding of the ecology of this species near its NLRM so that predictions regarding its response to climate change can be made with greater certainty. Based on the principles of ecological amplitude and limiting factors and studies of other tree species at their NLRM, we hypothesized that longleaf pine radial growth is responding to winter temperatures at its NLRM.

\section{MATERIALS AND METHODS}

\section{Study Area and Study Sites}

The study area is located in the Atlantic Coastal Plain longleaf pine ecoregion of southeastern Virginia. Elevation ranges from 0 to $30 \mathrm{~m}$ a.s.l. and the landscape is composed of shorelines, sand dunes, and middle-elevation ancient marine terraces dating as far back as the Miocene (Woods et al. 2005). Present-day Atlantic Coastal Plain upland forests consist of hickory (Carya sp.), shortleaf pine, loblolly pine, white oak (Quercus alba L.) and post oak (Quercus stellata Wangenh.), and bottomland forests include tupelos (Nyssa sp.), various oaks (Quercus sp.), and bald cypress (Taxodium distichum (L.) L.C. Rich.) (Woods et al. 2005). Prior to European settlement, longleaf pine occurred in pure and mixed forests, but only remnant populations exist in southeastern Virginia (Frost and Musselman 1987; Sheridan 1993; Sheridan et al. 1999; Frost 2006).

We studied the only two Virginia sites with naturally occurring and regenerated remnant longleaf pine, Everwoods (41.7 ha; $76^{\circ} 55^{\prime} 34^{\prime \prime} \mathrm{W}$, $36^{\circ} 39^{\prime} 30^{\prime \prime} \mathrm{N}$; ca. $12 \mathrm{~m}$ a.s.l.) and Seacock Swamp (312.8 ha; $76^{\circ} 55^{\prime} 2^{\prime \prime} \mathrm{W}, 36^{\circ} 49^{\prime} 45^{\prime \prime} \mathrm{N}$; ca. $12 \mathrm{~m}$ a.s.l.; about $48.3 \mathrm{~km}$ north of Everwoods). In these sites, longleaf pine is a component of the much larger closed-canopy, mixed hardwood-loblolly pine forest. Everwoods is owned and managed by International Paper and is described by them as a "naturally established pine site" because this stand has not been actively managed by International Paper or its predecessor, Union Camp, although the duration of non-active management is not documented (Harvey Darden, International Paper, personal communication). Everwoods was also not included in a survey of longleaf pine in Virginia (Sheridan et al. 1999), because it was unknown until 2001 when it was discovered by International Paper. Seacock Swamp is privately owned and, based on the owner's recollection, was subject to selective harvesting in 1953, which left remnant trees to reseed the site (T.L. Bain, landowner, personal communication). Neither site has any known record of natural or prescribed fire. Both study sites are within Virginia's Climate Division 1 (National Climatic Data Center). The average annual temperature for this region is $13.9^{\circ} \mathrm{C}$. The warmest months are July (mean $=$ $25.36^{\circ} \mathrm{C}$ ) and August (mean $\left.=24.59^{\circ} \mathrm{C}\right)$, and the coldest are January (mean $=3.39^{\circ} \mathrm{C}$ ) and February $\left(\right.$ mean $\left.=3.98^{\circ} \mathrm{C}\right)$. Mean annual precipitation is $93 \mathrm{~cm}$ with August being the wettest month. The USDA Soil Survey Geographic database indicate that soils at Everwoods consist of Alaga fine sands, Chipley sands, and Leon-Chipley sands, and they are very deep ranging from excessively to poorly drained. At Seacock Swamp, soils consist of Bibb sandy loams that are frequently flooded, and Emporia fine sandy loams, Nansemond loamy 
fine sands, Slagle fine sandy loams, and Uchee loamy sands that are all well drained.

\section{Field Methods, Laboratory Methods, and Tree- Ring and Climate analysis}

We relocated all longleaf pine originally surveyed by Sheridan (1993) at Seacock Swamp and in 2002 at Everwoods (unpublished data from P.L. Sheridan). Longleaf pines at Seacock Swamp were relocated using geo-referenced points provided by the Virginia Department of Forestry, and via field notes and tree tags at Everwoods (Sheridan 1993). We identified all longleaf pines surveyed by Sheridan, geo-referenced them, and measured their diameter at breast height (DBH $1.4 \mathrm{~m}$ ). We extracted two cores using an increment borer from opposing sides of all individuals $\leq 10.0 \mathrm{~cm} \mathrm{DBH}$. Cores were taken at a height of $20 \mathrm{~cm}$ and perpendicular to the slope (when present).

All cores were dried, mounted, sanded with increasingly fine sandpaper, and were crossdated using the marker-year list method (Stokes and Smiley 1968; Phipps 1985; Yamaguchi 1991). Annual rings were measured using the Velmex unislide tree-ring measuring system $(0.001 \mathrm{~mm}$ resolution). COFECHA was used to statistically verify our crossdating and create master tree-ring series for both sites (Holmes 1983; Grissino-Mayer 2001). To minimize the effects of endogenous and exogenous disturbance while maximizing the climate signal, we began by omitting individuals from the master series for both sites based on boundary-line growth patterns (Black and Abrams 2003; Black and Abrams 2005; Bhuta et al. 2008). We omitted individual trees cumulatively experiencing both moderate $(20 \%)$ and major $(50 \%)$ release events or those experiencing major $(50 \%)$ release events in their individual measurement series from the master series. COFECHA was used to re-verify our modified master tree-ring series. Following re-verification, geometrically-related growth trends for both sites were standardized using CRONOL. We constructed standard chronologies by fitting a negative exponential curve or linear regression line and then applying a biweight robust mean to reduce the effects of
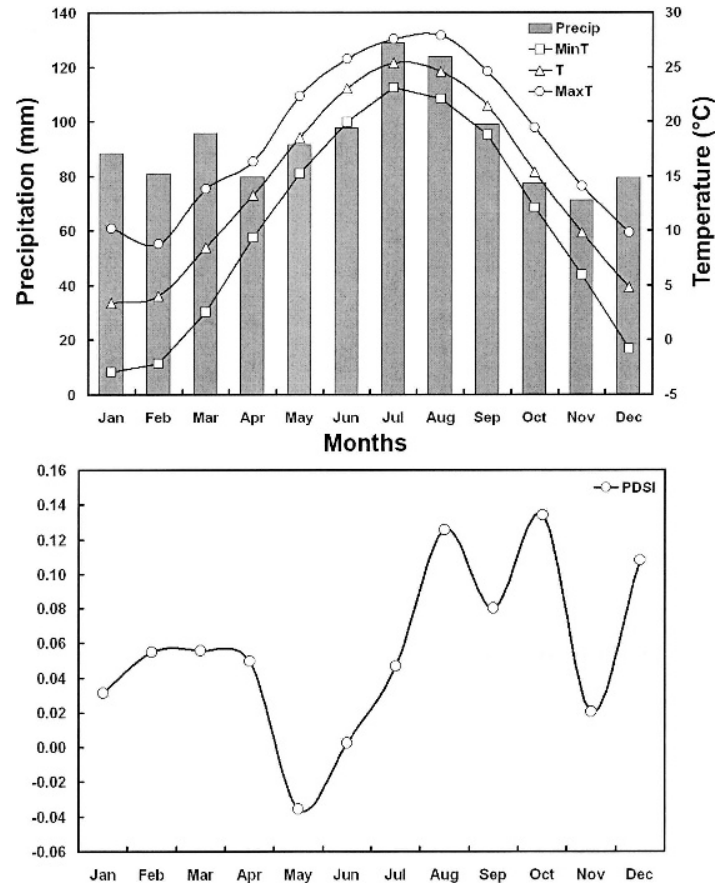

Figure 2. Climate diagram for precipitation; minimum, average, and maximum temperature; and Palmer Drought Severity Index (PDSI) for Virginia's Climate Division 1 (1896-2003) (NCDC 2006).

outliers for the individuals in the chronology (Cook 1985; Cook and Holmes 1992). Residual chronologies were constructed by applying autoregressive modeling to the detrended series for both sites to account for the effects of autocorrelation caused by interdependence with climate variables (Figure 2) (Cook 1985). The original and modified chronologies were compared to longleaf pine chronologies from Foster and Brooks (2001); Henderson and Grissino-Mayer (2009), and those made available through the National Oceanic and Atmospheric Administration's (NOAA) International Tree Ring Database (ITRDB). Longleaf pine chronologies from the ITRDB have been checked for quality control, providing insight into the quality and distribution of longleaf pine COFECHA descriptive statistics. The ITRDB chronologies used for comparison are the J. W. Jones Ecological Research Center in Georgia, Flomaton Natural Area in Alabama, and Jeffries Smokehouse, New Hill Beaver Tree Farm, and Weymouth Woods State Park in North Carolina. 


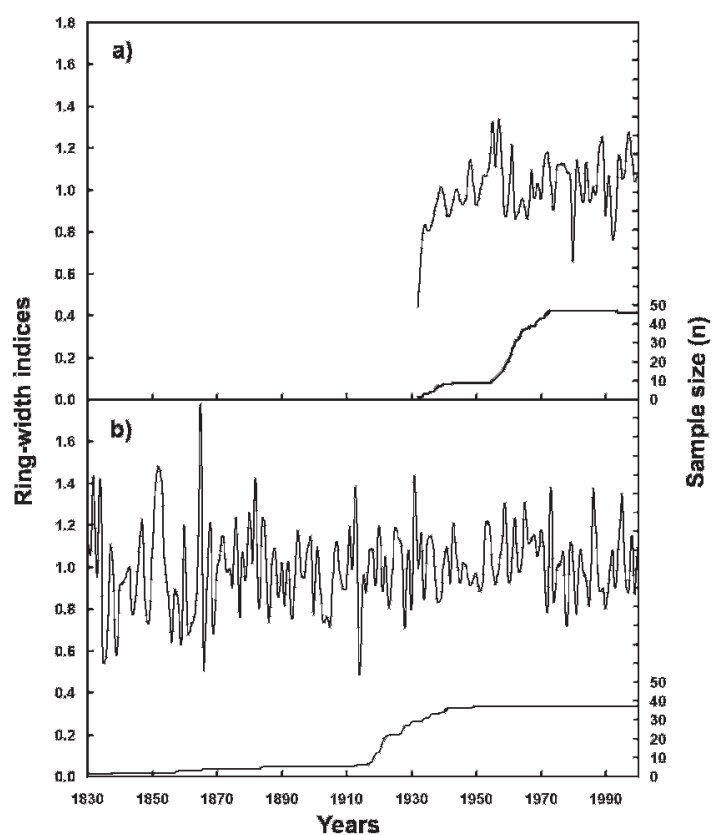

Figure 3. Residual chronologies for two sites in southeastern Virginia, a) Everwoods and b) Seacock Swamp, showing the number of samples for each year for both sites.

We obtained monthly mean precipitation, temperature, and Palmer Drought Severity Index (PDSI) data for Virginia's climate Division 1 from the National Climate Data Center, Asheville, NC (Figure 3). We used climate records averaged across the division instead of localized climate data from stations near the sites, because of missing data in the latter. Response function analysis (RFA) included monthly climatic variables covering the prior March to October of the current year of radial growth to account for the amount of carbon fixed and allocated to bolewood production and the maintenance of needles (Wahlenberg 1946; Meldahl et al. 1999; Foster and Brooks 2001). The response functions from 1933 to 2003 for Everwoods and 1897 to 2003 for Seacock Swamp were derived using the statistical program, DENDROCLIM2002 (Biondi and Waikul 2004). RFA, first described by Fritts et al. (1971), is a multiple linear regression technique incorporating principal components and accounts for the potential of co-linearity of monthly climatic variables on annual ring growth. Bootstrapping was added to this technique in order to avoid bias, limit error, and achieve more accurate results
(Efron 1979; Guiot 1991; Biondi and Waikul 2004). DENDROCLIM 2002 checks the statistical significance of response function coefficients with the bootstrap method and highlights coefficients exceeding the 95\% significance level (Guiot 1991; Biondi 1997; Biondi and Waikul 2004).

\section{RESULTS}

We found 12 more individuals at Everwoods than the 34 longleaf pine surveyed by Sheridan in 2002 (unpublished data). Cores from 37 of these trees were used for the Everwoods chronology. Of the original 41 individuals Sheridan (1993) surveyed in Seacock Swamp, we relocated and cored 32 of them. It is thought that the nine missing trees were downed by Hurricane Floyd in 1999 and harvested in 2001 (T.L. Bain, landowner, personal communication). Original master tree-ring series at Everwoods ranged in age from 32 to 184 years (mean $=53$ years, median $=45$ years, $\sigma=4.16$ ), while at Seacock Swamp the series ranged in age from 56 to 175 years of age (mean $=94$ years, median $=82.5$ years, $\sigma=5.47$ ). Our chronologies include eight trees over 100 years of age (one at Everwoods, seven at Seacock Swamp).

Although the number of dated series for both master chronologies was reduced through the removal of trees showing evidence of disturbance, the COFECHA descriptive statistics for both sites were not greatly affected. The series intercorrelation increased slightly while average mean sensitivity decreased slightly (Table 1). Further, average interseries correlation and average mean sensitivity of our original and modified chronologies are similar (Table 2) to longleaf pine chronologies from the ITRDB and the two recent studies (Foster and Brooks 2001; Henderson and Grissino-Mayer 2009). The average interseries correlation and average mean sensitivity are 0.503 and 0.248 for the modified Everwoods chronology, respectively, and 0.501 and 0.260 for the modified Seacock Swamp chronology, respectively. These modified chronologies were used in determining the response function for temperature, precipitation, and PDSI.

RFA indicates that radial growth at Everwoods responded positively to both current-year February temperature (RFA coefficient $=0.28$ ) 
Table 1. COFECHA descriptive statistics for longleaf pine at Everwoods and Seacock Swamp. Modified data represent chronologies after removing cores with $20 \%$ and $50 \%$ growth pulses based on boundary-line growth patterns. AIC = average interseries correlation and AMS = average mean sensitivity.

\begin{tabular}{lcccc}
\hline \multicolumn{1}{c}{ Site } & Everwoods & Everwoods (modified) & Seacock Swamp & Seacock Swamp (modified) \\
\hline Chronology length & $1819-2004$ & $1930-2003$ & $1829-2003$ & $1829-2003$ \\
Number of dated series & 58 & 47 & 49 & 37 \\
Total dated rings checked & 2924 & 2164 & 4332 & 3195 \\
AIC & 0.494 & 0.503 & 0.491 & 0.501 \\
AMS & 0.256 & 0.248 & 0.272 & 0.26 \\
\hline
\end{tabular}

and precipitation (RFA coefficient $=0.26$ ) and negatively to prior-year August PDSI (RFA coefficient $=-0.11$ ) (Figure 4). Radial growth at Seacock Swamp responded negatively to priorAugust PDSI (RFA coefficient $=-0.12$ ) and positively to current February temperature (RFA coefficient $=0.21$ ) and precipitation (RFA coefficient $=0.21)$. Other strong relationships were seen with prior August precipitation (RFA coefficient $=-0.16$ ) and current-year January PDSI $($ RFA coefficient $=0.134)$ at Seacock Swamp.

\section{DISCUSSION}

\section{Chronology Development and Climate Analysis}

We developed longleaf pine chronologies for southeastern Virginia and determined to which climatic variables these chronologies are responding. RFA supports the hypothesis that radial growth is responding to winter temperature for longleaf pine at its NLRM (Figure 4). In contrast, most studies have found no relationship or negative relationships between temperature and radial growth of longleaf pine (Lodewick 1930). Negative correlations have been found with August temperature in the Eastern Gulf Coastal and Southern Coastal Plain of southern Georgia (Coile 1936), with February through April temperature in the Eastern Gulf Coastal Plain of Alabama (Meldahl et al. 1999), and with summer temperatures in the Western Gulf Coastal Plain of Alabama (Henderson and Grissino-Mayer 2009). September temperatures along with August precipitation and February PDSI best predicted radial growth in the Eastern Gulf Coastal Plain

Table 2. COFECHA descriptive statistics for longleaf pine from other published sites and our study sites showing both unmodified and modified chronologies (with cores with $20 \%$ and $50 \%$ growth pulses based on boundary-line growth patterns removed). AIC $=$ average interseries correlation, AMS = average mean sensitivity, and NA = not available.

\begin{tabular}{|c|c|c|c|c|c|}
\hline Study Sites & Series length (years) & $\#$ of series & $\%$ Problem segments & AIC & AMS \\
\hline New Hill Beaver Tree Farm, NC ${ }^{a}$ & 99 & 31 & 4.95 & 0.531 & 0.245 \\
\hline Weymouth Woods State Park, NC ${ }^{\mathrm{a}}$ & 289 & 34 & 12.35 & 0.531 & 0.29 \\
\hline Flomaton Natural Area, $\mathrm{AL}^{\mathrm{a}, \mathrm{b}}$ & 181 & 43 & 0 & 0.603 & 0.279 \\
\hline J.W. Jones Ecological Research Center, GA ${ }^{\mathrm{a}}$ & 193 & 242 & 2.24 & 0.6 & 0.359 \\
\hline Jeffries Smokehouse, $\mathrm{NC}^{\mathrm{a}}$ & 221 & 31 & 34.76 & 0.428 & 0.301 \\
\hline USF Ecological Research Station, $\mathrm{FL}^{\mathrm{c}}$ & 52 & 8 & NA & 0.403 & 0.308 \\
\hline USF Ecological Research Station, $\mathrm{FL}^{\mathrm{c}}$ & 55 & 13 & NA & 0.458 & 0.332 \\
\hline Big Thicket National Reserve, $\mathrm{TX}^{\mathrm{d}}$ & 371 & 125 & NA & 0.52 & 0.35 \\
\hline Eglin Air Force Base, FL $^{\mathrm{d}}$ & 496 & 144 & NA & 0.51 & 0.31 \\
\hline Sandy Island, $\mathrm{SC}^{\mathrm{d}}$ & 545 & 105 & NA & 0.5 & 0.27 \\
\hline Everwoods, VA & 186 & 58 & 7.53 & 0.494 & 0.256 \\
\hline Everwoods, VA (modified chronology) & 75 & 47 & 4.62 & 0.503 & 0.248 \\
\hline Seacock Swamp, VA & 175 & 49 & 15.5 & 0.491 & 0.272 \\
\hline Seacock Swamp, VA (modified chronology) & 175 & 37 & 11.81 & 0.501 & 0.26 \\
\hline Mean & 222.4 & 69.1 & 10.4178 & 0.505 & 0.291 \\
\hline
\end{tabular}

${ }^{\mathrm{a}}$ ITRDB; ${ }^{\mathrm{b}}$ Meldahl et al. (1999); ${ }^{\mathrm{c}}$ Foster and Brooks (2001); ${ }^{\mathrm{d}}$ Henderson and Grissino-Mayer (2009). 


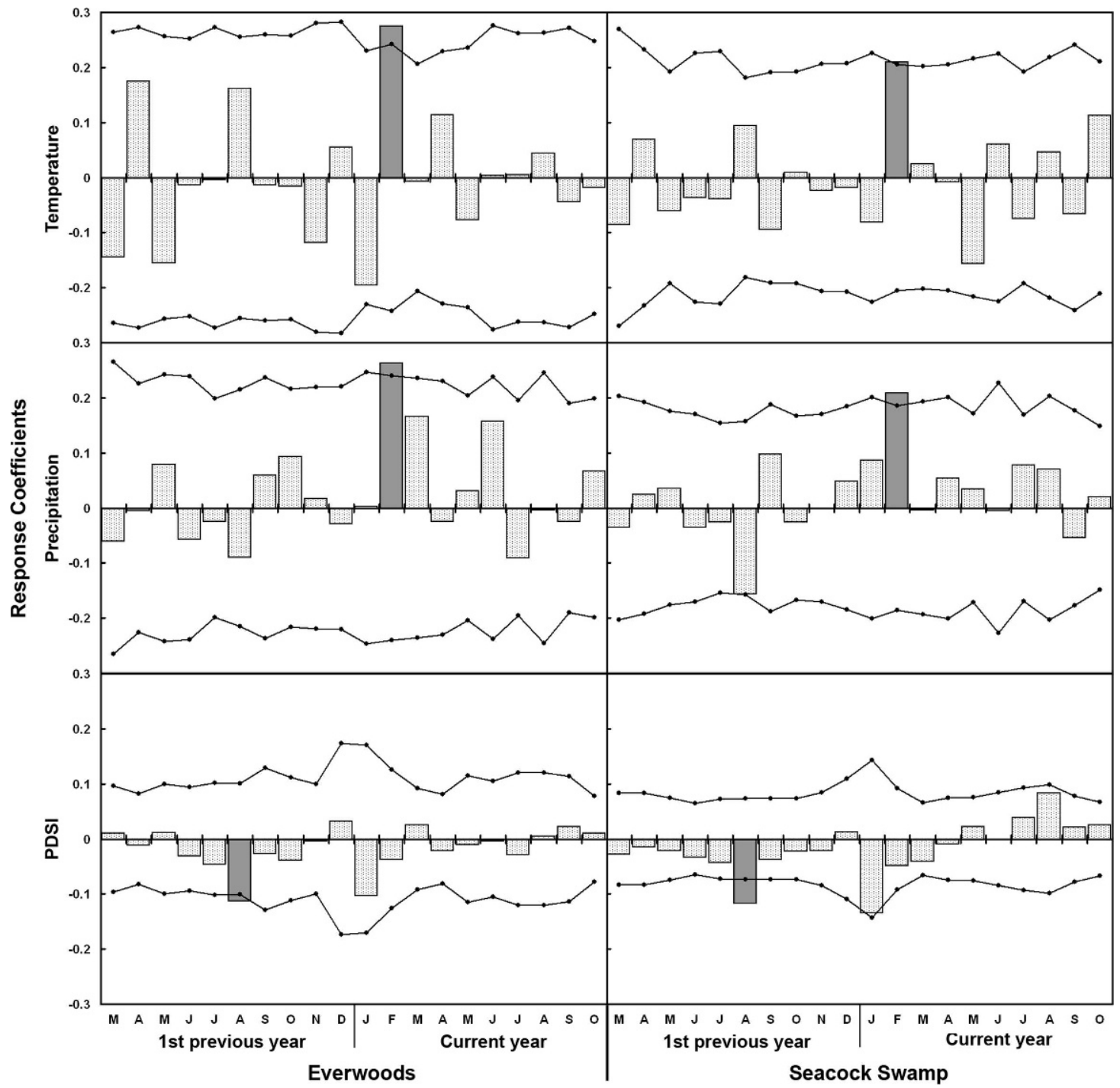

Figure 4. The correlation coefficients for temperature, precipitation, and PDSI against residual chronologies for Everwoods and Seacock Swamp. Grey bars indicate significant variables and black lines indicate the cutoff level at $95 \%$ significance.

of southern Mississippi as well as in the Southern Coastal Plain of southeastern Florida (Foster and Brooks 2001).

Because of the response to mean February temperature in this study, we hypothesize that winter temperatures strongly influenced the position of the NLRM for both longleaf and loblolly pine as climate fluctuated throughout the Holocene (Watts 1983; Wells et al. 1991; Schmidtling and Hipkins 1998; Schmidtling et al. 2000). This hypothesis is based on (1) the genetic diversity of allozymes for longleaf pine which decreases from west to east and from south to north, and (2) adaptive traits of longleaf pine growth and survival, which have a north-south component closely related to variation in mean annual minimum temperature (Schmidtling and Hipkins 1998). The north-south mean annual minimum temperature structure suggests that the NLRM of longleaf pine fluctuated as climate fluctuated. Further investigation of the relationship between radial growth and climate across its range will be 
one way to test this hypothesis. Regardless of the actual mechanism(s) that make longleaf pine sensitive to winter temperatures at the NLRM, our results support the hypothesis that radial growth is responding to winter temperature at its northern latitudinal range margin.

Our findings are also in agreement with other dendroclimatological studies showing winter temperature to be a significant influence on radial growth in other tree species, especially coniferous species growing near or at their NLRM (Cook et al. 1998; Tardif et al. 2001; Mäkinen et al. 2002; Pederson et al. 2004; Zhang and Hebda 2004; Hopton and Pederson 2005; Hoshino et al. 2008). Loblolly pine radial growth, the species most closely related to longleaf pine, is limited by cool winter temperatures at the eastern and western ends of its northern range limit. Winter photosynthesis has been observed in southeastern U.S. pines, especially in Piedmont loblolly pines of North Carolina (Hepting 1945; McGregor and Kramer 1963). If needles are not frozen, days with temperatures above freezing can allow temperate conifers to gain carbon (Chabot and Hicks 1982; Havranek and Tranquillini 1995). A gain of extraseasonal photosynthate can make up an important portion of a tree's annual carbon budget (Havranek and Tranquillini 1995). Loblolly pine growth at the northeastern end of its range margin has been significantly correlated to January and February minimum and maximum temperatures. This response might be caused by freezing or desiccation during these months when maximum temperatures can plummet below $10^{\circ} \mathrm{C}$ (Cook et al. 1998). Our results indicate that February temperature contributes to limiting the radial growth of longleaf pine at its NLRM, possibly for the same reasons postulated for loblolly pine.

Interestingly, results here support a growing body of literature indicating that the radial growth of conifers in the temperate eastern U.S. is constrained by winter temperatures. The radial growth of montane red spruce (Picea rubens Sarg.) is so constrained by winter temperatures that it was used for temperature reconstruction in New England (Conkey 1982). Subsequent research indicated high winter temperature sensitivity of red spruce across the Adirondack Mountains and much of northern New England (Johnson et al. 1988). Similarly, from southern Maine to northern New Jersey, radial growth of Atlantic white cedar is significantly limited by winter temperatures (Pederson et al. 2004; Hopton and Pederson 2005). In fact, more than half of the seven sites studied by Hopton and Pederson (2005) had temperature sensitivities similar to red spruce studied by Conkey (1982). Other conifers having winter-temperature sensitivity, though to a lesser degree, include eastern hemlock (Cook and Cole 1991) and pitch pine (Pederson et al. 2004). Eastern hemlock has a consistent positive correlation to current-March temperatures and reaches its highest values near its NLRM in northern Wisconsin, the Upper Peninsula of Michigan and the Adirondack Mountains of New York. Pitch pine has a significant positive correlation to prior-December and current-February temperatures in a northern range margin population in the Hudson River Valley of New York State. Combined with our findings here and prior research, it seems that further research is warranted for coniferous species along their NLRM and throughout much of their range in temperate eastern North America.

Our data also indicate that longleaf pine is responding to current February precipitation at their NLRM in southeast Virginia. This differs from the findings of several other longleaf pine studies that found current spring and summer precipitation has significant influence on radial growth (Devall et al. 1991; Meldahl et al. 1999; Foster and Brooks 2001; Henderson and GrissinoMayer 2009). A potential explanation of the lack of a strong drought response at longleaf pine's NLRM is that the evaporative demand during the growing season at this northerly latitude is less than what typically causes population-level water stress. Much replication is needed to better understand water stress at longleaf pine's NLRM. The significant relationship to February precipitation found here, however, is in agreement with longleaf pine studies in South Carolina and Texas (Henderson and Grissino-Mayer 2009). In this study, longleaf pine's significant inverse relationship with prior-year August PDSI indicates that radial growth increases with decreased water availability (increased evaporative demand). This 
unusual result makes further investigation along longleaf pine's NLRM even more important so that this finding can be understood as an anomaly or common climatic response.

\section{Management Implications}

Similar to the prediction for loblolly pine by Cook et al. (1998), longleaf pine might naturally expand northward beyond its present NLRM in southeastern Virginia because of rising temperatures. However, this scenario might still require reforestation and management efforts because of the limited distribution of naturally occurring longleaf pine populations and fragmented landscape within the study region. If future winter temperatures increase in southeastern Virginia, winter temperature stress on the radial growth is expected to decrease and resemble the lack of positive correlation to winter temperatures in more southerly loblolly pines (Cook et al. 1998). A potential offset to a reduction of winter temperature stress, however, could come in the form of increased drought stress during the growing season. Therefore, any gains made by warmer winter temperatures could be negated by increased drought. On the other hand, increased drought might increase the likelihood of fire and favor longleaf pine at the expense of other conifers and hardwoods currently dominating these sites (Gilliam and Platt 1999).

Ultimately, local and regional variation in soils, topography, and land use might also influence climate stress on longleaf pine growth. Factors influencing longleaf pine's establishment and growth are complex in their interactions and could potentially mask or amplify one another in the future. Thus, we suggest that many of these factors should be considered and monitored as management and restoration strategies are conceived and implemented in southeastern Virginia and nearby regions where populations of longleaf pine are limited. Management that accounts for potential climate change scenarios will be necessary to preserve present populations and maintain reforestation efforts for this state-listed critically imperiled species (Iverson et al. 1999; Frost 2006; Pederson et al. 2008).

\section{CONCLUSIONS}

This study determined that (1) chronologies can be developed for longleaf pine at its northern latitudinal range margin, (2) current-year winter temperature and precipitation and prior-year August PDSI significantly influence radial growth of longleaf pine at its NLRM in Virginia, and (3) there is variability in longleaf pine radial growth's response to climate through out its range. As predicted for many tree species, longleaf pine's NLRM might fluctuate because of future climatic conditions. Management plans that incorporate the restoration/afforestation of longleaf pine in the fragmented landscape of southeastern Virginia need to account for this warming, but increased drought, and possibly fire, which ultimately might favor longleaf pine over other southern pines and hardwoods, could complicate these plans.

Our research also highlights the variability of the relationship between longleaf pine radial growth and climate, and the need for further research on this relationship in other parts of its range. Clearly, large spatial gaps are apparent between our study sites in Virginia and those in the southern and western parts of the longleaf pine range. Information regarding the relationship between the radial growth of longleaf pine and climate are also seen in its northern range margins of Alabama, Georgia, North Carolina, and South Carolina. Research that fills in the gap on the spatial variations of the relationship between longleaf pine radial growth and climate between our sites and those observed in prior research would contribute to a better understanding of the ecology and natural history of this species. Such research might also aid in explaining past distributions and enhancing predictions of future distributions under changing climate.

\section{ACKNOWLEDGMENTS}

This research was funded in part by the Sidman P. Poole Scholarship, Department of Geography, Virginia Tech, and the Graduate School at Virginia Tech. We thank Philip Sheridan for field assistance, access to unpublished data, and other contributions; William "Billy" Apperson, Virginia Department of Forestry, for geo- 
referenced data for Seacock Swamp; Ben Logan and John R. Winston for field assistance; International Paper, particularly Harvey Darden and T.L. Bain for access to and information on their properties (our sites); and Justin Hart, Henri Grissino-Mayer, and two anonymous reviewers for helpful comments on earlier drafts of this manuscript.

\section{REFERENCES CITED}

Bhuta, A. A. R., L. M. Kennedy, C. A. Copenheaver, P. M. Sheridan, and J. B. Campbell, 2008. Boundary-line growth patterns to determine disturbance history of remnant longleaf pine (Pinus palustris P. Mill.) in mixed forest of southeastern Virginia. Journal of the Torrey Botanical Society 135:516-529.

Biondi, F., 1997. Evolutionary and moving response functions in dendroclimatology. Dendrochronologia 15:139-150.

Biondi, F., and K. Waikul, 2004. DENDROCLIM2002: A C++ program for statistical calibration of climate signals in tree ring chronologies. Computers and Geosciences 30:303-311.

Black, B. A., and M. D. Abrams, 2003. Use of boundary-line growth patterns as a basis for dendroecological release criteria. Ecological Applications 13:1733-1749.

, 2005. Disturbance history and climate response in an old-growth hemlock-white pine forest, central Pennsylvania. Journal of the Torrey Botanical Society 132:103-114.

Chabot, B. F., and D. J. Hicks, 1982. The ecology of leaf life spans. Annual Review of Ecology and Systematics 13:229-59.

Coile, T. S., 1936. The effect of rainfall and temperature on the annual radial growth of pine in the southern United States. Ecological Monographs 6:533-62.

Conkey, L. E., 1982. Temperature reconstructions in the Northeastern United States. In Climate From Tree Rings, edited by M. K. Hughes, Cambridge University Press, Cambridge, UK; pp. 165-167.

Cook, E. R., 1985. A Time Series Analysis Approach to Treering Standardization. Ph.D. dissertation, University of Arizona, Tucson; 171 pp.

Cook, E. R., and J. Cole, 1991. Predicting the response of forests in eastern North America to future climatic change. Climatic Change 19:271-282.

Cook, E. R., and R. L. Holmes, 1992. Program CRONOL, in The International Tree-Ring Date Bank Program Library Version 2.0 User's Manual, edited by H. D. Grissino-Mayer, R. L. Holmes, and H. C. Fritts, University of Arizona, Tuscon, Arizona, USA.

Cook, E. R., W. L. Nance, P. J. Krusic, and J. Grissom, 1998. Modeling the differential sensitivity of loblolly pine to climatic change using tree rings. In The Productivity and Sustainability of Southern Forest Ecosystems in a Changing Environment, edited by S. Fox, and R. A. Mickler, pp. 717-739. Springer, New York.

Devall, M. S., J. M. Grender, and J. Koretz, 1991. Dendroecological analysis of longleaf pine (Pinus palustris) forest in Mississippi. Vegetatio 93:1-8.
Efron, B., 1979. Bootstrap methods: Another look at the jackknife. The Annals of Statistics 7:1-26.

Ford, C. R., and J. R. Brooks, 2003. Hydrological and climatic responses of Pinus elliottii var. densa in mesic pine flatwoods Florida, USA. Annals of Forest Science 60:385-392.

Foster, T. E., and J. R. Brooks, 2001. Long-term trends in growth of Pinus palustris and Pinus elliottii along a hydrological gradient in central Florida. Canadian Journal of Forest Research 31:1661-1670.

Friend, A. L., and W. L. Hafley, 1989. Climatic limitations to growth in loblolly and shortleaf pine (Pinus taeda and $P$. echinata): A dendroclimatological approach. Forest Ecology and Management 26:113-122.

Fritts, H. C., 1976. Tree Rings and Climate. Academic Press, New York; 567 pp.

Fritts, H. C., T. J. Blasing, B. P. Hayden, and J. E. Kutzbach, 1971. Multivariate techniques for specifying tree-growth and climate relationships and for reconstructing anomalies in paleoclimate. Journal of Applied Meteorology 10:845-864.

Frost, C. C., and L. J. Musselman, 1987. History and vegetation of the Blackwater Ecologic Preserve. Castanea 52:16-46.

Frost, C. C., 2006. History and future of the longleaf pine ecosystem. In The Longleaf Pine Ecosystem: Ecology, Silviculture, and Restoration, edited by S. Jose, E. J. Jokela, and D. L. Miller, pp. 9-42. Springer, New York.

Gilliam, F. S., and W. J. Platt, 1999. Effects of long-term fire exclusion on tree species composition and stand structure in an old-growth Pinus palustris (longleaf pine) forest. Plant Ecology 140:15-26.

Grissino-Mayer, H. D., 2001. Evaluating crossdating accuracy: A manual and tutorial for the computer program COFECHA. Tree-Ring Research 57:205-221.

Grissino-Mayer, H. D., M. S. Rosenberger, and D. R. Butler, 1989. Climatic response in tree rings of loblolly pine from north Georgia. Physical Geography 10:32-43.

Grissino-Mayer, H. D., and D. R. Butler, 1993. Effects of climate on growth of shortleaf pine (Pinus echinata Mill.) in northern Georgia: A dendroclimatic study. Southeastern Geographer 33:65-81.

Guiot, J., 1991. The bootsrapped response function. Tree-Ring Bulletin 51:39-41.

Havranek, M., and W. Tranquillini, 1995. Physiological processes during their winter dormancy and their ecological significance. In Ecophysiology of Coniferous Forest, edited by W. K. Smith, and T. M. Hinkley, pp. 95-124. Academic Press, New York.

Henderson, J. P., and Grissino-Mayer, H. D., 2009. Climatetree growth relationship of longleaf pine (Pinus palustris Mill.) in the Southeastern Coastal Plain, USA. Dendrochronologia 27:31-43.

Hepting, G. H., 1945. Reserve food storage in shortleaf pine in relation to little-leaf disease. Pathology 35:106-119.

Holmes, R. L., 1983. Computer-assisted quality control in treering dating and measurement. Tree-Ring Bulletin 43:69-78.

Hopton, H. M., and N. Pederson, 2005. Climate sensitivity of Atlantic white-cedar at its northern range limit. In Atlantic White Cedar: Ecology, Restoration and Management, Proceedings of the Arlington Echo Symposium, June 2-4 2003, 
Millersville, MD, General Technical Report SRS-91, pp. 22-30. Southern Research Station, USDA Forest Service, Asheville, North Carolina.

Hoshino, Y., H. Yonenobu, K. Yasue, Y. Nobori, and T. Mitsutani, 2008. On the radial-growth variations of Japanese beech (Fagus crentata) on the northernmost part of Honshu Island, Japan. Journal of Wood Science 54:183-188.

Iverson, L. R., A. M. Prasad, B. J. Hale, and E. K. Sutherland, 1999. An atlas of current and potential future distributions of common trees of the eastern United States. General Technical Report NE-265. Northeastern Research Station, USDA Forest Service, Newton Square, Pennsylvania; 245 pp.

Johnson, A. H., E. R. Cook, and T. G. Siccama, 1988. Climate and red spruce growth and decline in the northern Appalachians. Proceedings of the National Academy of Sciences 85:5369-5373.

Lodewick, J. E., 1930. Effect of certain climatic factors on the diameter growth of longleaf pine in western Florida. Journal of Agricultural Research 41:349-363.

Mäkinen, H., P. Nöjd, H-P. Kahle, U. Neumann, B. Tveite, K. Mielkäinen, H. Röhle, and H. Spiecker, 2002. Radial growth variation of Norway spruce (Picea abies (L.) Karst.) across latitudinal and altitudinal gradients in central and northern Europe. Forest Ecology and Management 171:243-259.

McGregor, W. H. D., and P. J. Kramer, 1963. Seasonal trends in rates of photosynthesis and respiration of loblolly pine. American Journal of Botany 50:760-765.

Meldahl, R. S., Pederson, N., Kush, J. S., and Varner, IIIJ. M., 1999. Dendrochronological investigations of climate and competitive effects on longleaf pine growth. In Tree Ring Analysis: Biological, Methodological and Environmental Aspects, edited by R. Wimmer, and R. E. Vetter, pp. 265-85. CABI Publishing, Oxfordshire, UK.

Pederson, N., E. R. Cook, G. C. Jacoby, D. M. Peteet, and K. L. Griffin, 2004. The influence of winter temperatures on the annual radial growth of six northern range margin tree species. Dendrochronologia 22:7-29.

Pederson, N., J. M. Varner, III, and B. J. Palik, 2008. Canopy disturbance and tree recruitment over two centuries in a managed longleaf pine landscape. Forest Ecology and Manangment 254:85-95.

Peet, R. K., 2006. Ecological classification of longleaf pine woodlands In The Longleaf Pine Ecosystem: Ecology, Silviculture, and Restoration, edited by S. Jose, E. J. Jokela, and D. L. Miller, pp. 51-94. Springer, New York.

Phipps, R. L., 1985. Collecting, preparing, crossdating, and measuring tree increment cores. US Geological Survey, Water Resource Investigations Report 85-4148; 48 pp.

Schmidtling, R. C., and V. Hipkins, 1998. Genetic diversity in longleaf pine (Pinus palustris): Influence of historical and prehistorical events. Canadian Journal of Forest Research 28: 1135-1145.

Schmidtling, R. C., V. Hipkins, and E. Carroll, 2000. Pleistocene refugia for longleaf and loblolly pines. Journal of Sustainable Forestry 10:349-354.

Schumacher, E. X., and B. B. Day, 1939. The influence of precipitation upon the width of annual rings of certain timber trees. Ecological Monographs 9:387-429.
Sheridan, P. M., 1993. A relict longleaf pine occurrence in northern Southampton County, Virginia. Virginia Journal of Science 44:122.

Sheridan, P. M., J. Scrivani, N. Penick, and A. Simpson, 1999. A census of longleaf pine in Virginia. In Longleaf Pine: A Forward Look. Proceedings of the Second Longleaf Alliance Conference, edited by Kush, J. S., pp. 154-162. Auburn University, Auburn, Alabama.

Shreve, F., 1914. The role of winter temperature in determining the distribution of plants. American Journal of Botany 1: 194-202.

Stokes, M. A., and T. W. Smiley, 1968. An Introduction to TreeRing Dating. University of Arizona Press, Tucson; 73 pp.

Tardif, J., J. Brisson, and Y. Bergeron, 2001. Dendroclimatic analysis of Acer saccharum, Fagus grandifolia, and Tsuga Canadensis from an old-growth forest, southwestern Quebec. Canadian Journal of Forest Research 31:1491-1501.

Tardif, J., F. Conciatori, P. Nantel, and D. Gagnon, 2006. Radial growth and climate responses of white oak (Quercus alba) and northern red oak (Quercus rubra), southwestern Quebec, Canada. Journal of Biogeography 33:1657-1669.

Travis, D. J., and V. Meentemeyer, 1991. Influence of glaze ice storms on growth rates of loblolly pine Pinus taeda and shortleaf pine Pinus echinata in the Southern Appalachian Piedmont. Climate Research 1:199-205.

Wahlenberg, W. G., 1946. Longleaf Pine: Its Use, Ecology, Regeneration, Protection, and Management. Charles Lathrop Pack Forestry Foundation, Washington D.C.; 429 pp.

Watts, W. A., 1983. A vegetational history of the eastern United States 25,000 to 10,000 years ago. In The Late Pleistocene. Vol. I. Late-Quaternary Environments of the United States, edited by S. C. Porter, pp. 294-310. University of Minnesota Press, Minneapolis.

Wells, O. O., G. L. Switzer, and R. C. Schmidtling, 1991. Geographic variation in Mississippi loblolly pine and sweetgum. Silvae Genetica 40:105-118.

Woods, A. J., J. M. Omernik, and D. D. Brown, 2005. Ecoregions of North America. http://www.epa.gov/wed/pages/ ecoregions.htm. Western Ecology Division of the U.S. Environmental Protection Agency, Corvallis, Oregon.

Yamaguchi, D. K., 1991. A simple method for cross-dating increment cores from living trees. Canadian Journal of Forest Research 21:414-6.

Zahner, R., 1989. Tree-ring series related to stand and environmental factors in South Alabama Pinus palustris stands. In Proceedings of the Fifth Biennial Southern Silvicultural Research Conference, General Technical Report SO-74, edited by J. H. Miller, pp. 193-197. Southern Forest Experiment Station, USDA, Forest Service, Asheville, North Carolina.

Zhang, Q-B., and R. J. Hebda, 2004. Radial growth patterns of Pseudotsuga menziesii along an elevational gradient on the central coast of British Columbia. Canadian Journal of Forest Research 34:1946-1954.

Received 16 October 2008; accepted 26 February 2009. 